\section{UTILITY OF RESEARCH OF CARDIAC BIOMARKERS FOR EARLY DIAGNOSIS OF ANTHRACYCLINE INDUCED CARDIOTOXICITY IN CHILDREN}

doi:10.1136/archdischild-2012-302724.1528

L Dimitiru. Medex Medical Center, lasi, Romania

Background Anthracycline-induced cardiotoxicity in children with malignant diseases often may be associated with significant changes in values of some cardiac biomarkers.

Objective To establish the value of research of cardiac biomarkers for early diagnosis of anthracycline induced cardiotoxicity.

Methods Patients, 46 children (aged 2 months - 18 years), treated with anthracyclines for malignant hemopathies. Control group: 20 healthy children without history of cardiac diseases. Patients and controls were investgated by: clinical exam, Doppler echocardiography (Echo), determination of plasma values of of cardiac biomarkers $\mathrm{BNP}$ (B natriuretic peptide) and cTnI (troponin).

Results Determination of cardiac biomarkers: *Increased plasma levels of BNP in $45.7 \%$ of patients, from a mean baseline of $89 \mathrm{ng} / \mathrm{ml}$ $(0-117 \mathrm{ng} / \mathrm{ml})$ to alue $240 \mathrm{ng} / \mathrm{ml}(0-810 \mathrm{ng} / \mathrm{ml}),{ }^{*}$ increasing cTnI values. plasma at $4.34 \%$ of cases, the initial values $<0.04 \mathrm{pg} / \mathrm{ml}$ to values $>0.04 \mathrm{pg} / \mathrm{ml}$ in 2 cases. Echo modifications: anthracycline induced cardiomyopathy or just only diastolic dysfunction of LV in majority of cases, often correlated with cumulative dose of anthracyclines. Biomarkers changes were correlated in most cases with the presence of clinical manifestations and echo modifications induced by anthracycline cardiotoxicity.

Conclusions Clinical or infraclinical manifestations of cardiotoxicity in children treated with anthracyclines is associated with increased levels of cardiac biomarkers: BNP and cTnI which is an useful marker for the.cardiotoxicity. Changes in this parameters appeared early than echo modifications in anthracicline induced cardiotoxicity and is necessary to systematic monitoring these parameters during and after cytostatic therapy.

\section{THE STUDY OF THE EFFECT OF CUMIN SEEDS EXTRACTS ON SOME PATHOGENIC BACTERIAL AGENTS}

doi:10.1136/archdischild-2012-302724.1529

${ }^{1} \mathrm{M}$ Motamedifar, ${ }^{2} \mathrm{G}$ Haghighati, ${ }^{2} \mathrm{~A}$ Yousefi Arvand. ${ }^{1}$ Department of Bacteriology and Virology, Shiraz AIDS Research Center (SHARC), Shiraz University of Medical Sciences; ${ }^{2}$ Department of Bacteriology and Virology, Medical School, Shiraz University of Medical Sciences, Shiraz, Iran

Background and Aims The antimicrobial effects of cumin (Cuminum cyminum L.), as an agent, have been mentioned previously. In this study the inhibitory effect of alcoholic and aqueous extracts on some Gram positive and Gram negative pathogenic bacteria was examined.

Methods Susceptibility of different standard bacterial strains to the prepared methanolic and aqueous extracts were studied by using disk diffusion method in comparison with penicillin and amikacin antibiotics. The bacteria studied were Escherichia coli (ATCC 25922), Pseudomonas aeruginosa (ATCC 27853), Kelebsiella pneumoniae (ATCC 10031), Bacillus cereus (ATCC 11778), meticillin susceptible Staphylococcus aureus (MSSA) ATCC 25923 and meticillin resistant Staphylococcus aureus (MRSA) ATCC 700698. The minimum inhibitory concentration (MIC) of extracts was also determined when necessary.

Results The Methanolic and aqueous extracts of Cuminum cyminum $(25-100 \mathrm{mg} / \mathrm{mL})$ caused growth inhibition zones of $S$. aureus with the diameter ranged ranging from 9.6-22.4 mm and 14-23.2 $\mathrm{mm}$ respectively. For MRSA growth inhibition zones ranged 13-23.4 $\mathrm{mm}$ for alcoholic extracts and 11-13.2 $\mathrm{mm}$ for the aqueous extract. For MSSA Staphylococci the methanolic extract caused inhibition diameter of $13 \mathrm{~mm}$ and aqueous extract with the diameter of 10-13 $\mathrm{mm}$. These extracts were ineffective on other investigated bacteria. MIC of alcoholic extracts for MRSA (700698) and MSSA (25923) was determined as $75 \pm 35.36 \mathrm{mg} / \mathrm{mL}$.

Conclusions Considering the antibacterial effects of alcoholic and aqueous extracts of cumin seeds on $S$. aureus observed in this investigation, continuing the research for studying the in-vivo effect of ant- microbial effects of Cunminum cyminum extracts on Staphylococci seems valuable.

\section{THE COMPARISON OF SEVERAL ANESTHETIC PREMEDICATION IN MAGNETIC RESONANCE IMAGINING (MRI) UNIT IN PEDIATRIC PATIENTS}

doi:10.1136/archdischild-2012-302724.1530

'V Tuna, ${ }^{2} \mathrm{MS}$ Çolak, ${ }^{2} \mathrm{H}$ Ulusoy, ${ }^{2} \mathrm{M}$ Kosucu. ${ }^{1}$ Trabzon Kanuni Eğitim ve Araştırma Hastanemize; ${ }^{2}$ Karadeniz Technical University, Faculty of Medicine, Trabzon, Turkey

We were aimed to compare the efficacy and safety of midazolam, tramadol and midazolam plus tramadol in magnetic resonance imaging for pediatric patients.

Undergoing MRI, for premedication, doses of midazolam 0.75 $\mathrm{mg} / \mathrm{kg}$, tramadol $3 \mathrm{mg} / \mathrm{kg}$ and midazolam $0,375 \mathrm{mg} / \mathrm{kg}+$ tramadol $1.5 \mathrm{mg} / \mathrm{kg}$ were administered. Undergoing MRI, these drugs were determined sedation, anxiety and separation scores, and compared the effects of exposure time, shots of the family and technician satisfaction, reliability and the side effects. Sixty pediatric patients undergoing MRI were selected prospective and randomly

From patients with ASA I-II risk groups, patients in 1-15 years olds were administered orally premedication before 30 minutes from sedation. After MRI, sedation, anxiety and separation scores in anesthesia recovery unit, the time of undergoing MRI and staying in recovery unit, the frequency of additional sedative drugs administration and the family and technician satisfaction were noted. In addition, follow up was vital parameters and side effects.

The efficiency of sedation in midazolam group was determined better than other groups. In tramadol group, there was not efficiently sedation. For this reason, the need of additional sedation was occurred and prolonged undergoing MRI time. In midazolam+tramadol group, anxiety was lesser than other groups. Comparing the other groups there was maximum nausea side effect in tramadol group and minimum in midazolam+tramadol group.

In conclusion, midazolam group, the best sedation was detected. The use of low dose combination of midazolam+tramadol was not effective for sedation but was decrease anxiety scores and adaptation of separation time in children undergoing MRI.

\section{DRUGS ADMINISTERED IN SICKLE CELL DISEASE VASO-OCLUSIVE CRISIS}

doi:10.1136/archdischild-2012-302724.1531

'MZ Delago, 'P Aliaga, ${ }^{2} \mathrm{M}$ Bandeira, ${ }^{3} \mathrm{CA}$ Teixeira, ${ }^{4} \mathrm{FJ}$ Ropero, ${ }^{5} \mathrm{~S}$ Taniguchi. ${ }^{1}$ Albert

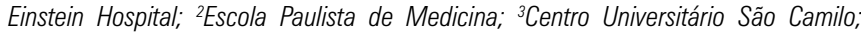
${ }^{4}$ UFABC; ${ }^{5}$ Basic Sciences, Albert Einstein Hospital, São Paulo, Brazil

Background and Aims The vascular occlusion of small vessels with blood cells in sickle cell disease leads to clinical manifestation such as pain crisis and organs' chronic damage.

Objective To study the drugs administered for pain treatment in patients with sickle cell disease vaso-oclusive episodes.

Methods Our study included 40 patients with sickle cell disease with mean age $8.95 \pm 0.6$ years old under pain treatment.

Results Clinical manifestations observed were vaso-oclusive crisis $(100 \%)$, splenomegaly $(17.5 \%)$, stroke $(5 \%)$,icteric syndrome $(5 \%)$, acute chest syndrome (2.5\%), dyspnea (32.5\%).

Patients with mild pain $(10 \%)$ received dipyrone $22 \mathrm{mg} / \mathrm{kg}$ every 6 hours (100\%) and tramadol $1.1 \mathrm{mg} / \mathrm{kg} \mathrm{q} 4-8 \mathrm{~h}(75 \%)$. 
Patients with moderate pain (52\%) received dypirone $19 \mathrm{mg} / \mathrm{kg} \mathrm{q}$ 6 hours (86\%) and tramadol $1.1 \mathrm{mg} / \mathrm{kg} \mathrm{q} 4-8 \mathrm{~h}(95 \%)$ and morphine $0.1 \mathrm{mg} / \mathrm{kg}$ every $3-6$ hours (33\%).

Patients with severe pain $(37.5 \%)$ received dypirone $19 \mathrm{mg} / \mathrm{kg} \mathrm{q}$ 6 hours $(93 \%)$ and tramadol $1.2 \mathrm{mg} / \mathrm{kg} \mathrm{q} 4-8 \mathrm{~h}(93 \%)$ and morphine $0.1 \mathrm{mg} / \mathrm{kg}$ every 3-6 hours (60\%).

Patients who received tramadol i.v. in intervals over 6 hours (12.5\%), and received morphine i.v.in intervals over 4 hours $(10 \%)$ had moderate and intense pain.

Conclusions Tramadol and morphine i.v. should not be administered in intervals longer than 6 hours for tramadol and 4 hours for morphine due to its half life. (Tramadol T1/2:5.5.h and morphine T1/2: 2 hours).

Since dypirone inhibits cicloxigenase and reduces tromboxane levels in platelets, antiagregant effect should be evaluated in sickle cell disease patients.

\section{HEPATITIS A IN PEDIATRIC WARD (EXPERIENCE IN THE PEDIATRIC SERVICE OF CHU OF BATNA)}

doi:10.1136/archdischild-2012-302724.1532

ND Righi, S Brahmi, H Zerguine, H Soltani, S Tebbal. CHU Benflis Touhami, Universite de Batna, Park Aforage, Algeria

Introduction Hepatitis $A$ is a real public health problem worldwide: 273 confirmed cases in Algeria in 2010. She is responsible for $10-30 \%$ of hepatitis in adults and $70-90 \%$ in children.

Objectives To determine the frequency and severity of hepatitis A. Materials and Methods A retrospective study done on the records of patients hospitalized for complicated form of hepatitis A over a period of 02 years (2009-2010). 28 patients hospitalized for complicated forms: signs of liver failure.

Results Incidence: $1.15 \%$.

Age group affected is between 5-10 years with a female predominance.

In Algeria the transmission is the predominant waterborne, mostly occurring in winter. Fever, vomiting and asthenia constitute $68.74 \%$ of the reasons for consultation. The average AST, ALT was elevated 100 times normal.

Conclusion Hepatitis A is very common in Algeria in connection with a water-borne and the majority of cases are asymptomatic and almost at the age of 18 years $95 \%$ of patients develop antibodies.

\section{EPIDEMIOLOGICAL PROFILE OF URINARY TRACT INFECTION IN PEDIATRIC WARD (EXPERIENCE OF A PEDIATRIC SERVICE OF THE UNIVERSITY HOSPITAL OF BATNA)}

doi:10.1136/archdischild-2012-302724.1533

HD Zerguine, S Brahmi, S Taleb, S Tebbal. Sciences Médicales de Batna, CHU de Batna, Logements, Algeria

Introduction Urinary tract infection (UTI) is one of the most common infectious attacks in children, Pediatrics significant problem for many reasons: its incidence, the polymorphism of clinical manifestations, its potential severity (renal scarring), the possibility of revealing a uropathy.

Objective Evaluate the incidence, morbidity and long-term acute (hypertension, renal failure), the proportion of bacterial strains involved and how they supported.

Materials and Methods Retrospective study done on the records of patients hospitalized in pediatric ward from 01-01-2009 until 31-12-2009.

130 patients were the subject of this study.

Results Incidence: 4.64\%.

Frequently females (sex ratio 0.68 ). The age group most affected is from 30 days to 05 years (range $30 \mathrm{~d}$ and 15).
Fever was noted in 110 patients, 44 patients complained of urinary symptoms. The gross hematuria was observed in 07 patients.

leukocytosis was present in $84.62 \%$ of cases; an ESR above 30 in the first hour in $34.61 \%$ cases. CRP was positive in $65.38 \%$ of patients.

E coli in $22.38 \%$ cases, followed in descending order of pneumoniedans klebsiella, pseudomonas aeroginosa, Proteus, enterococcus.

Ultrasound renal disease $17.16 \%$ (7.58\% urétérohydronephrose).

The UCR pathological in $9.70 \%$ (6\% RVU).

Pathological IVU 5.22\% (3\% urétérohydronéphrose).

Conclusion This study confirmed the frequency of UTI in a pediatric setting. However, great efforts are still needed to better support her.

Better knowledge of bacteriology Local: prevalence of germs, sero-typing, with ATB resistance;

The long-term prophylactic treatment of UI also remains to be defined.

Supprimer RépondreRépondre Faire suivreDéplacerImprimer Actions Suivant Précédent.

\section{SEVOFLURANE ANESTHESIA SIDE EFFECTS IN PEDIATRIC PATIENTS UNDERGOING RADIOTHERAPY}

doi:10.1136/archdischild-2012-302724.1534

${ }^{1} \mathrm{M}$ Feltrin, ${ }^{2} \mathrm{AFY}$ Centroni, ${ }^{3} \mathrm{MA}$ Santos, ${ }^{1} \mathrm{CM}$ Vaz, ${ }^{1} \mathrm{MC}$ Nascimento, ${ }^{4} \mathrm{~J}$ Ropero, ${ }^{1} \mathrm{PG}$ Aires, 'S Taniguchi. 'Albert Einstein Hospital; ${ }^{2}$ Oncology; ${ }^{3}$ AMA Paraisópolis, Albert Einstein Hospital; ${ }^{4}$ UFABC, São Paulo, Brazil

Background and Aims Sevoflurane anesthesia is related to high incidence of emergence agitation in pediatric patients.

Methods Our retrospective study included 38 pediatric patients with mean age $29 \pm 3.94$ months, weight mean $14.64 \pm 0.55 \mathrm{~kg}$ undergoing radiotherapy.

Results Patients with retinoblastoma 55.26\% (21), meduloblastoma $23.68 \%$ (9) and malignant neoplasm of cerebellum $21.10 \%$ (8) which received radiotherapy $27.79 \pm 2.16$ sessions were studied.

Sevoflurane $8 \%$ were administered to $100 \%$ of these patients for anesthesia induction and maintenance.

The anesthesia duration was $32.62 \pm 2.41$ minutes.

Emergence agitation, nausea and allergic reaction were observed.

The incidence of emergence agitation during the anesthesia recovery was observed in $84.21 \%$ (32) compared to $15.79 \%$ (6) no agitation side effect patients.

Nausea was observed in $10.53 \%$ and allergic reaction recorded in $5.26 \%$ of patients.

Either propofol $0.5-4.4 \mathrm{mg} / \mathrm{kg}$ administered to $34.38 \%$ (11) patients or nalbuphine $0.1-0.15 \mathrm{mg} / \mathrm{kg}$ given to $6.25 \%$ (2) patients or fentanyl $2-3.6 \mathrm{mg} / \mathrm{kg}$ given to $3.12 \%$ (1), controlled the emergence agitation induced by sevoflurane anesthesia.

No treatment was applied to $56.25 \%$ (18).

Conclusions The association of propofol or nalbuphine to sevoflurane was effective controlling emergence agitation induced by sevoflurane anesthesia in children undergoing radiotherapy.

Stable vital signs were registered previously and after sevoflurane.

One case of anaphylactic reaction was observed in patients undergoing anesthesia with sevoflurane.

\section{5 \\ NATIONAL TASK FORCE ON SAFE PEDIATRIC MEDICATIONS: IMPROVE THE ACESS TO LIQUID FORMULATIONS}

doi:10.1136/archdischild-2012-302724.1535

${ }^{1} \mathrm{O}$ Carvalho, ${ }^{1} \mathrm{D}$ Duarte, ${ }^{2} \mathrm{C}$ Teixeira de Barros, ${ }^{3} \mathrm{D}$ Palma, ${ }^{4} \mathrm{H}$ Jardim, ${ }^{5} \mathrm{M}$ Almeida, ${ }^{6} \mathrm{~T}$ Tomé ${ }^{1}$ INFARMED, IP; ${ }^{2}$ Faculdade de Farmácia, Universidade de Lisboa, Lisbon; ${ }^{3}$ Hospital Dr. José Almeida, Cascais; ${ }^{4}$ Centro Hospitalar do Porto, EPE, Porto; ${ }^{5}$ Dep. Pediatria CHL Norte, Lisboa; ${ }^{6} \mathrm{CHL}$ Central, MAC, Lisbon, Portugal 